\title{
COMPARATIVE ANALYSIS OF DEMOGRAPHICAL SITUATION OF BORDER AREAS AFFECTED BY THE CHERNOBYL ACCIDENT (EXAMPLE OF RIVNE AND GOMEL REGIONS)
}

\author{
Anastasia GREBIN \\ Nizhyn Gogol State University, Nizhyn, Ukraine \\ serg1234serg@meta.ua
}

\begin{abstract}
Advisability of studies of the border areas is caused by the necessity to intensify their development, adoption and use of the experience of neighboring countries for solution of the most pressing social and economic problems. Rivne region of Ukraine and Gomel region of Belarus were chosen for comparative assessment of the demographic situation in the border areas, because they share a border and are characterized by similar natural developmental prerequisites. Moreover, Rivne and Gomel regions suffer from significant radioactive contamination as a result of the Chernobyl accident. Despite the fact that these regions locate in different countries, they have a similar nature of the demographic processes. However, level of demographic severity is lower in Rivne region than in Gomel region, due to a higher birth rate (14.6\%o and $12.3 \%$ respectively) and positive values of natural increase ( $2.1 \%$ against $-0.8 \%$ o). The age structure of the population is worse in the Gomel region, since the proportion of persons of retirement age is $22.6 \%$, while in Rivne region it is $18 \%$. The study demonstrated the more favorable conditions for demographic situation in the Rivne region, i.e. lower level of urbanization, greater religiosity of the population and a higher share of people of genital age etc. The high death rate among people of working age is the most acute demographic problem for both regions. Reason of its situation is radioactive contamination of territories and crisis processes in economy. The study tested radiation induced diseases by means of correlation analysis. These are hyperplasia of the thyroid gland, blood diseases, diseases of digestive system and cancerous neoplasms. Demographic forecasting is among the objectives of the perspective study of population of Gomel and Rivne regions.

Key words: border areas, demographic processes, natural movement of population, morbidity, infant mortality.
\end{abstract}

UDC: $911.3: 314(477.81 / 476.2)$

\section{ПОРІВНЯЛЬНИЙ АНАЛІЗ ДЕМОГРАФІЧНОЇ СИТУАЦІЇ ПРИКОРДОННИХ ТЕРИТОРІЙ, ЩО ПОСТРАЖДАЛИ ВІД АВАРІЇ НА ЧОРНОБИЛЬСЬКІЙ АЕС (НА ПРИКЛАДІ РІВНЕНСЬКОї ТА ГОМЕЛЬСЬКОї ОБЛАСТЕЙ)}

\author{
Анастасія ГРЕБІНЬ \\ Ніжинський державний університет імені Миколи Гоголя, Ніжин, Україна \\ serg1234serg@meta.ua
}

\begin{abstract}
Анотація: Доцільність дослідження прикордонних територій зумовлена необхідністю активізації їхнього розвитку, запозичення та використання досвіду сусідніх країн у вирішенні найбільш гострих соціально-економічних проблем. Для порівняльної оцінки особливостей демографічної ситуації у прикордонних регіонах було обрано Рівненську область України та Гомельську область Республіки Білорусь, які мають спільний кордон, характеризуються подібними природними передумовами розвитку і зазнали значного радіоактивного забруднення у результаті аварії на Чорнобильській АЕС. Попри те, що зазначені регіони розміщується у різних країнах, вони мають подібний характер перебігу демографічних процесів. Водночас у Рівненській області рівень гостроти демографічної ситуації нижчий, ніж у Гомельській, завдяки вищому показнику народжуваності (14,6\%о та 12,3\%о відповідно) та додатньому значенню природного приросту (2,1\%о проти -0,8\%о). Гіршою у Гомельській області $\epsilon$ також вікова структура населення, оскільки частка осіб пенсійного віку становить тут 22,6\%, тоді як у Рівненській - 18\%. Встановлено, що більш сприятливий стан демографічній ситуації у Рівненській області визначається нижчим рівнем її урбанізованості, вищою релігійністю населення та вищою часткою осіб плідного віку. Найгострішою демографічною проблемою для обох областей $\epsilon$ висока смертність серед осіб працездатного віку, зумовлена переважно радіоактивним забрудненням їхніх територій та кризовими процесами в економіці. На основі використання кореляційного аналізу виявлено раціаційно індуковані захворювання, до яких належать гіперплазія щитовидної залози, захворювання крові, травної системи та злоякісні новоутворення. Визначено, що серед перспективних завдань дослідження населення Гомельської та Рівненської областей, $є$ здійснення демографічного прогнозування.
\end{abstract}

Ключові слова: прикордонні території, демографічні процеси, природний рух населення, захворюваність, дитяча смертність

\section{УдК: $911.3: 314(477.81 / 476.2)$}

Вступ. Постановка проблеми. Вивченню прикордонних територій в останні роки приділяється значна увага, що зумовлено необхідністю активізації їхнього розвитку. Починаючи з середини 90-х років XX ст. між Україною та сусідніми державами створено низку єврорегіонів, до складу яких вхо-

(C) А. Гребінь дять майже всі прикордонні області нашої країни. У рамках зазначених єврорегіонів розроблено цілу низку різноманітних проектів, реалізація яких має сприяти стимулюванню розвитку прикордонних територій, подоланню буферності державного кордону, активізації зовнішньої торгівлі тощо.

Демографічна проблематика належить до числа тих спільних проектів, які досить часто вивчаються 
науковцями суміжних країн. Дуже актуальною залишається зазначена проблематика для Рівненської області України та Гомельської області Республіки Білорусь, оскільки вони, по-перше, є прикордонними і мають схожі особливості розвитку, по-друге, чи не найбільше постраждали від аварії на ЧАЕС, що вплинуло на формування кількісного складу та рівня гостроти демографічної ситуації. Результати порівняльного аналізу особливостей природного руху населення у сусідніх прикордонних областях розширить можливості науковців та управлінців у пошуку найбільш ефективних шляхів покращання демографічної ситуації у них.

Аналіз останніх досліджень і публікацій. Дослідження прикордонних територій має багатоаспектний характер і включає широке коло питань - від обгрунтування створення єврорегіонів і розвитку зовнішньоекономічних зв'язків, до аналізу соціально-економічних та екологічних процесів. Вагомі здобутки у вивченні прикордонних територій мають П.Бєлєнький, Д.Думітраш, Г.Кулєшова, П.Луцишин, Н.Мікула, Г.Підгрушний та інші науковці.

Аналіз наукових досліджень із вивчення особливостей розвитку прикордонних територій показав, що вони здійснюються переважно у рамках реалізації спільних проектів діючих єврорегіонів. Рівненська область не входить до складу жодного із єврорегіонів, хоча займає прикордонне положення. Саме цим пояснюється незначний обсяг наукових праць, присвячених аналізу демографічних процесів у цьому регіоні. Окремі аспекти демографічної проблематики Рівненської області відображені у роботах Ю.Кушнірук та Л.Волкової [4;5], де вони розглядаються у контексті медико-екологічної оцінки території, а також у колективній монографії [1], присвяченій дослідженню сільських територій Полісся.

Вивченню демографічних проблем Гомельської області присвячена значна кількість наукових праць, проте найбільш вагомі результати викладені у роботах Т.Шафаренко, Т.Флерко, А.Океанова, Л.Лобанка.

Формулювання цілей статті. Постановка завдання. Доцільність поглибленого аналізу демографічної ситуації Рівненської та Гомельської областей визначається перш за все необхідністю порівняльної оцінки показників природного руху населення на територіях, які зазнали значного радіоактивного забруднення у результаті аварії на Чорнобильській AEC у межах різних країн, запозичення досвіду сусідніх держав у вирішенні екологічних і медико-демографічних проблем.

Головним завданням даного дослідження є порівняльний аналіз демографічної ситуації Рівненської та Гомельської областей, виявлення iii найгостріших проблем i розробка стратегічних напрямів щодо їх розв'язання.

Виклад основного матеріалу. Демографічна ситуація є важливою характеристикою соціальноекономічного розвитку будь-якої території. Вона відображається низкою показників (народжуваність, смертність, природний приріст тощо), які найдоцільніше розглядати в динаміці. Статистичну базу дослідження склали дані головних управлінь статистики у Рівненській та Гомельській областях у розрізі їхніх адміністративних районів.

Рівненська область на тлі інших областей України вирізняється найвищими показниками народжуваності та додатнім природним приростом населення. Загальна динаміка показника народжуваності характеризується хвилеподібністю. Упродовж 1993-2000 pр. в області, як і загалом в Україні, спостерігалося падіння показника народжуваності. В останні майже 15 років показник народжуваності у Рівненській області мав тенден-цію до зростання і тепер стабілізувався на рівні 14,8 \%о (табл. 1).

Показники смертності в даному регіоні мали подібну динаміку. Упродовж 1995-2005 pp. вони погіршувалися, в останні роки набули сталого характеру ізупинилися на рівні 12,5-12,7\%о. Рівненська область належить до тих небагатьох регіонів України, які в останні роки характеризуються додатнім природним приростом, який у 2014 р. становив 2,1\%о.

Через відносно високі показники народжуваності Рівненська область вирізняється досить сприятливою віковою структурою населення. Частка дитячого населення складає тут $21 \%$, пенсійного $18 \%$ (табл. 2). У статевій структурі населення регіону переважають жінки, частка яких становить 53\%.

Попри те, що Гомельська область знаходиться в іншій країні, динаміка головних демографічних показників у ній подібна до Рівненської області. Це пояснюється схожістю соціально-економічних процесів, які проходили у країнах колишнього СРСР. Найгірші показники народжуваності та смертності спостерігалися у Гомельській області у кінці 90-х років XX ст. та на початку 2000-х років XXI ст. (табл. 1), що було зумовлено складною економічною ситуацією i падінням рівня життя населення. Водночас у Гомельській області, на відміну від Рівненської, зберігається від'ємний природний приріст (-0,8\%). Гіршою від Рівненської області є тут також вікова структура, оскільки частка дитячого населення становить 16,5\%, а пенсійного - 22,6\%. Втім за показниками дитячої смертності ситуація у Гомельській області є більш сприятливою.

Проведений порівняльний аналіз демографічних характеристик показав, що у Рівненській та Гомельській областях вони значною мірою подібні, а найбільш гострою проблемою для них залишаються високі показники смертності населення, особливо серед чоловіків працездатного віку. Підтвердженням зазначеного є той факт, що смертність чоловіків у віковій групі 30-44 роки в Україні в 4,9 рази вища від країн ЄС. У Республіці Білорусь частка чоловіків серед померлих у працездатному віці становить майже $82 \%$. Не менш гострою проблемою $є$ високі показники дитячої смертності, особливо у Рівненській області. Пошук відповіді на питання чим зумовлена така ситуація потребує додаткового аналізу показників захворюваності населення та ㄲi причин.

Як уже зазначалося, обидві області значною 
Таблиияя 1

Динаміка показників народжуваності та смертності Рівненської і Гомельської областей, \%о

\begin{tabular}{|l|c|c|c|c|c|}
\hline & 1995 & 2000 & 2005 & 2010 & 2014 \\
\hline \multicolumn{5}{|c|}{ Рівненська область } \\
\hline Народжуваність & 13,8 & 11,8 & 12,5 & 14,8 & 14,8 \\
\hline Смертність & 12,8 & 13,1 & 14,2 & 13,0 & 12,7 \\
\hline \multicolumn{5}{|c|}{ Гомельська область } \\
\hline Народжуваність & 10,3 & 9,6 & 9,6 & 11,6 & 12,8 \\
\hline Смертність & 13,6 & 14,0 & 15,1 & 15,1 & 13,6 \\
\hline
\end{tabular}

Складено за даними головних управлінь статистики Рівненської та Гомельської областей [2; 3$]$

Таблиия 2

Показники дитячої смертності та структури населення Рівненської та Гомельської областей

\begin{tabular}{|l|c|c|}
\hline & Рівненська область & Гомельська область \\
\hline Смертність немовлят до 1 року, \%о & 8,3 & 3,1 \\
\hline Вікова структура, \% & & 16,5 \\
\hline $0-15$ рр. & 21 & 61,1 \\
\hline $16-59$ рр. & 61 & 22,4 \\
\hline Понад 60 р. & 18 & $47 / 53$ \\
\hline Співвідношення між чоловіками та жінками, \% & $47 / 53$ & $66,9 / 77,9$ \\
\hline Тривалість життя, років: чоловіки/жінки & $66 / 77$ & \\
\hline
\end{tabular}

Складено за даними головних управлінь статистики Рівненської та Гомельської областей

Показники кореляційної залежності між радіаційним забрудненням території Рівненської області цезієм-137 та захворюваністю населення (2013р.)

\begin{tabular}{|c|c|c|c|c|c|c|c|}
\hline \multicolumn{10}{|c|}{ Захворювання } \\
\hline $\begin{array}{c}\text { Новоут- } \\
\text { ворення }\end{array}$ & Крові & $\begin{array}{c}\text { Ендок- } \\
\text { ринної } \\
\text { системи }\end{array}$ & $\begin{array}{c}\text { Системи } \\
\text { кровообігу }\end{array}$ & $\begin{array}{c}\text { Органів } \\
\text { дихання }\end{array}$ & $\begin{array}{c}\text { Органів } \\
\text { травлення }\end{array}$ & $\begin{array}{c}\text { Вроджені } \\
\text { аномалії } \\
\text { розвитку }\end{array}$ & $\begin{array}{c}\text { Онколо- } \\
\text { гічні }\end{array}$ \\
\hline 0,46 & 0,54 & 0,69 & 0,14 & 0,26 & 0,51 & 0,18 & 0,48 \\
\hline
\end{tabular}

Розраховано автором за даними головного управління статистики у Рівненській області
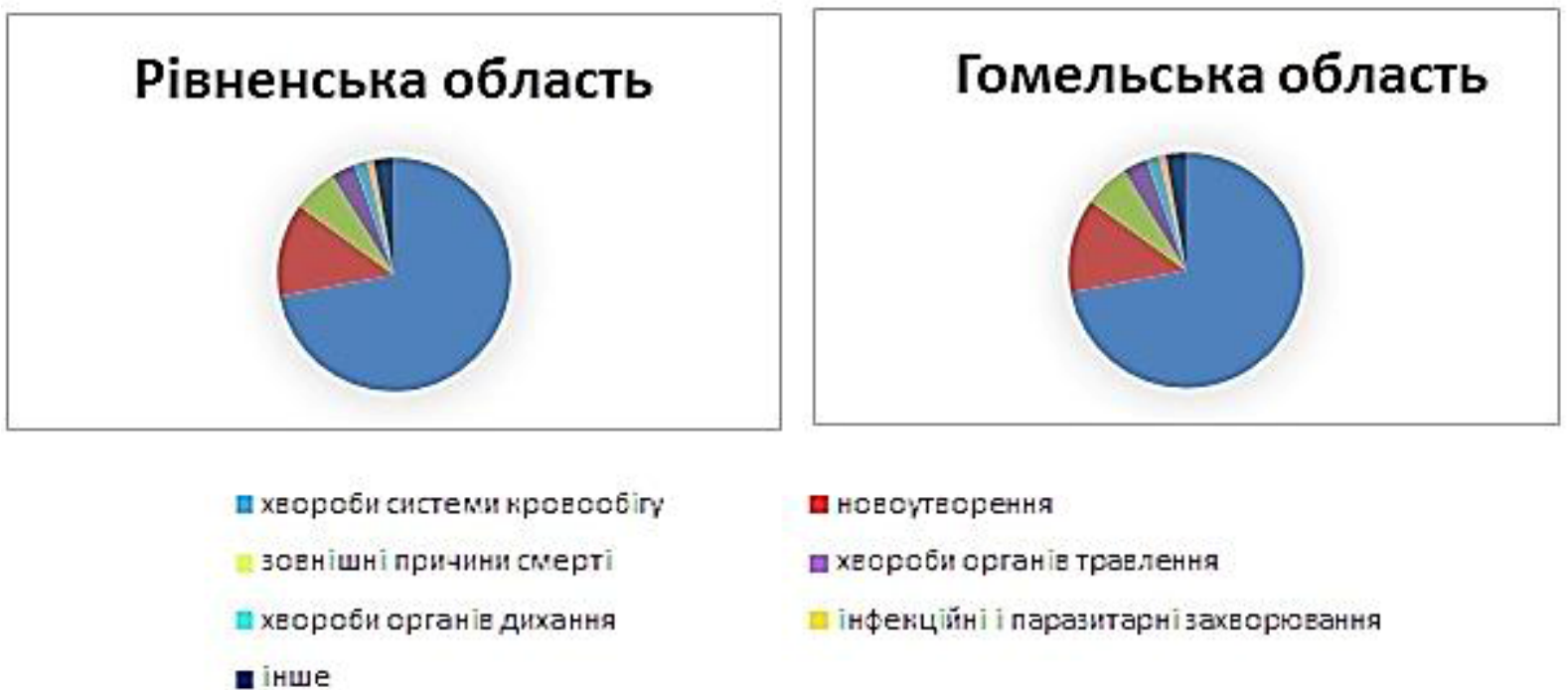

Побудовано автором за даними головного управління статистики Рівненської області та бази даних «Здоров'я для всіх» Республіки Білорусь

Рис. 1. Структура основних причин смертності населення Рівненської та Гомельської областей, 2014 р. 
мірою постраждали від аварії на ЧАЕС. Наприклад у Гомельській області мешкає майже $75 \%$ усього населення, яке проживає на радіоактивно забруднених територіях у Республіці Білорусь.

Всесвітня організація охорони здоров'я пропонує розглядати показник дитячої смертності як інтегральний індикатор суспільного здоров'я регіону. Високі показники дитячої смертності часто пояснюються саме складною екологічною ситуацією, що впливає на репродуктивну функцію жінок i визначає високі показники перинатальної смертності - від 28 тижнів вагітності до 7 днів після народження дитини. Не можна недооцінювати також рівень і доступність медичної допомоги, освіти і культури населення, значення новонароджених у системі суспільних цінностей, нестабільність сімейних стосунків. Індикатором останнього є частка дітей, народжених поза шлюбом. У Рівненській області, де вищий рівень релігійності населення та шанування інституту шлюбу, частка народжених поза шлюбом становить 9,8\%, у Гомельській - 16,1\%.

Питання високої смертності населення працездатного віку давно перебуває у полі зору науковців, зокрема медиків, екологів, біологів, географів, однак ще більшої актуальності ця проблема набула після аварії на ЧАЕС. Результатом цієї катастрофи стало різке збільшення чисельності радіаційно зумовлених хвороб і підвищення загального рівня захворюваності населення. Серед радіаційно індукованих хвороб Рівненської області варто виділити захворювання ендокринної системи, крові, травної системи та онкологічні захворювання. Такий висновок дозволяють зробити обчислення показників кореляційної залежності між окремими видами захворюваності населення та рівнем забрудненості території Рівненської області цезієм137 (табл. 3).

Що стосується показників захворюваності населення Гомельської області, то варто зазначити, що в їх структурі найбільшу частку займають хвороби органів дихання - 51,3\%, на другому місці йдуть травми, отруєння та інші наслідки впливу зовнішніх чинників - 12\%, на третьому - хвороби кістково-м'язової системи та сполучної тканини $9,9 \%$.

Захворювання системи кровообігу знаходиться на сьомому місці у структурі захворюваності населення Гомельської області, однак саме вони $\epsilon$ основною причино смерті населення - 54,5\% (рис. 1). При цьому визначальним фактором, який призводить до порушень у системі кровообігу, є артеріальна гіпертензія. Загалом структура основних причин смертності населення в обох областях є дуже подібною (рис. 1).

Поряд із показниками стану екологічної ситуації, на рівень смертності населення впливають також рівень урбанізованості території та особливості статево-вікової структури населення.

Проведене дослідження показало, що смертність населення у сільській місцевості є вищою, ніж у містах. Наприклад у Рівненській області це перевищення становить 52,8\%. Більш високі показники смертності у сільській місцевості зумовлені гіршими умовами життя населення - низькою якістю питної води і продуктів харчування (відсутність радіологічного контролю), низьким рівнем розвитку медичної допомоги.

Вагомою передумовою формування загального стану здоров'я населення регіону i величини показників смертності $€$ вікова структура. Як уже зазначалося, вікова структура населення Рівненської області є більш сприятливою, оскільки у ній відносно незначна частка населення старших вікових груп.

На сьогодні серед першочергових завдань демографічної політики даних регіонів має бути збереження здоров'я населення. Високі рівні захворюваності серед дітей вимагають особливої турботи про їх здоров'я, що полягає у забезпечення їх якісними продуктами харчування та чистою питною водою; збагачення їх раціону продуктами, які виводять радіоактивні елементи 3 організму і сприяють його здоровому розвитку. Важливою віхою у збереженні здорового стану дітей є реструктуризація та оновлення системи оздоровчих організацій i доступна можливість для кожної родини користуватися цими послугами. Водночас досить актуальним $\epsilon$ питання поліпшення репродуктивного здоров'я населення, забезпечення доступності якісної медико-генетичної, акушерської допомоги, пропаганди сучасних засобів планування сім'ї, a також створення i забезпечення повноцінного функціонування регіональних центрів високоспеціалізованої медичної допомоги населенню та інтенсивний розвиток швидкої невідкладної медичної допомоги, насамперед, у сільській місцевості.

Висновки. Перспективи подальших досліджень. Проведений порівняльний аналіз демографічної ситуації Рівненської та Гомельської областей дає підстави сформулювати такі висновки.

1. Стимулювання розвитку прикордонних територій неможливе без детального аналізу їхньої соціально-економічної ситуації, при цьому важливу роль відіграє вивчення демографічних процесів.

2. Дослідження демографічної ситуації Рівненської та Гомельської областей зумовлене необхідністю порівняльної оцінки показників природного руху населення на територіях, що зазнали радіоактивного забруднення.

3. Демографічна ситуація у Рівненській та Гомельській областях має ряд спільних і відмінних рис. Незважаючи на подібну динаміку основних демографічних процесів упродовж 1995-2014 pp., тепер спостерігаються значні відмінності у віковій структурі та рівні природного приросту населення.

4. У результаті дослідження були виявлені найгостріші демографічні проблеми цих прикордонних територій - високі рівні дитячої смертності та смертність чоловіків працездатного віку, а також значне поширення радіаційно індукованих хвороб.

5. Поряд із складною екологічною ситуацією, важливу роль у формуванні суспільного здоров'я населення, у перебігу демографічних процесів у 
Рівненській та Гомельській областях відіграють рівень урбанізації та вікова структура населення.

Вивчення демографічної ситуації будь-якої території є складним багатоаспектним завданням. Окрім порівняльної оцінки існуючих демографічних показників прикордонних областей, доцільно було б скласти науково обгрунтовані прогнози основних демографічних складових. Значної уваги потребують також дослідження захворюваності населення, особливо у контексті того, що Рівненська та Гомельська області зазнали значного радіоактивного забруднення.

\section{References:}

1. Alêšugìna N., Baranovs'kij M., Baranovs'ka O. et al. Sil ’s'ki depresivnì teritoriï Polìssâ: osoblivostì rozvitku ta sanaciï: monografîa [Polissya rural depressed areas: features of development and recovery: monograph. Edited by M. O. Baranovsky and V. I. Kutcenko. Nizhun, Nizhun Gogol State University Press, 2010, 315 p. (In Ukrainian).

2. Department of Statistics in Rivne region]. Available at: http://www.rv.ukrstat.gov.ua/ (In Ukrainian).

3. General Statistical Office of the Gomel region. Available at: http://gomel.belstat.gov.by (In Ukrainian).

4. Kušnìruk Û., Skripčuk P. Ekologo-demografičnì problemi Rivnens'koï oblastì [Ecological and demographic problems ofRivneregion].VisnikRivnens'kogoderžavnogotehničnogouniversitetu. Tehničninauki. Sil's'kogospodars'ki nauki [Journal of Rivne State Technical University. Engineering. Agriculture], 2000, Vol. 3 (5), Part 1, pp. 53-61. (In Ukrainian).

5. VolkovaL., KušnìrukÛ. Aspekti sučasnogo mediko-ekologičnogo riziku teritorïi Rìvnens'koï oblastì [Aspects of modern medical and environmental risk in Rivne region]. Problemi Zahidnogo Polissâ. Naukovij vìsnik Nadslučans' kogo institutu: Zbirnik naukovih prac' [Problems of Western Polesie. Scientific Bulletin of Nadsluchanskyi Institute: Collection of scientific papers]. Berezne, 2007, Vol. 27, pp. 51-54. (In Ukrainian). 